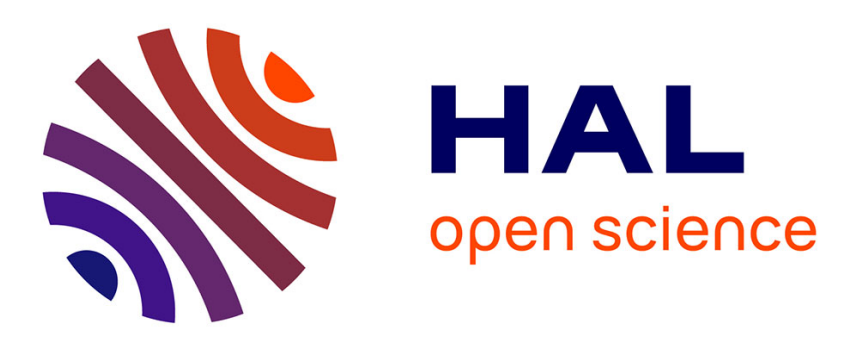

\title{
Self-insurance and multi-peril grassland crop insurance: the case of French suckler cow farms
}

\author{
Claire Mosnier
}

\section{To cite this version:}

Claire Mosnier. Self-insurance and multi-peril grassland crop insurance: the case of French suckler cow farms. Agricultural Finance Review, 2015, 75 (4), pp.533-551. 10.1108/AFR-02-2015-0006 . hal-01241707

\section{HAL Id: hal-01241707 https://hal.science/hal-01241707}

Submitted on 10 Dec 2015

HAL is a multi-disciplinary open access archive for the deposit and dissemination of scientific research documents, whether they are published or not. The documents may come from teaching and research institutions in France or abroad, or from public or private research centers.
L'archive ouverte pluridisciplinaire HAL, est destinée au dépôt et à la diffusion de documents scientifiques de niveau recherche, publiés ou non, émanant des établissements d'enseignement et de recherche français ou étrangers, des laboratoires publics ou privés. 


\section{Self-insurance and multi-peril grassland crop insurance: the case of French suckler cow farms}

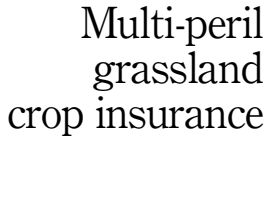

533

\author{
UMRH-EGEE, INRA, UMR 1213-Herbivores, \\ F-63122 Saint-Genès Champanelle, France
}

Claire Mosnier

\begin{abstract}
Purpose - From the perspectives of the probable replacement of the national calamity funds by multi-peril grassland insurance, the purpose of this paper is to estimate demand for grassland production insurance. Design/methodology/approach - A discrete stochastic programming model with a three-year planning horizon was used to run simulations for farms raising suckler cows primarily with grasslands. In this model, the annual area insured and some production decisions are optimized under grasland yield uncertainty, with possible ex post production-system adjustments. The effects of insurance loading cost (14 levels), insurance coverage level (three levels), risk aversion (two levels) and stock levels (forage and animal stocks vary according to grassland yields and to farm management of the previous years) were analyzed.

Findings - The results show that grassland insurance could be used as a flexible risk management tool, when farm becomes vulnerable to fodder shortfall. According to previous years' grassland yields and to the subsequent states of hay stock and animal liveweight, the area insured could vary between nearly the none and full. Farmers with low-average stocking rate and important hay storage capacity have less incentive to buy grassland insurance. The author also demonstrates that for a given loading cost, more insurance is purchased at a coverage level of 70 percent of average yield than at higher coverage levels. The cost of self-insurance increases for important and rare losses while multi-peril grassland insurance premium decreases. Higher levels of risk aversion also raise the quantity of insurance subscribed. Eventually, insurance price is a key factor. Almost no insurance is bought for loading costs greater than 1.1 under low-risk aversion and for loading costs greater than 1.3 under moderate risk aversion.
\end{abstract}

Research limitations/implications - The willingness to pay for insurance could have been overestimated for different reasons. First, basis risks have not been introduced in the simulation framework. Although the Forage Production Index performed quite well, basis risks are high enough to trigger inappropriate indemnifications in some cases. Consequences of these risks should be estimated in further research. Second, other self-insurance options and public emergency measures such as subsidized loan or reduction in social security contributions should also be considered to assess and reduce farmers vulnerability to risks.

Practical implications - The launching of the multi-peril grassland insurance is likely to be successful thanks to the 65 percent of public subsidies on insurance premiuml. However, considering that the loading cost is likely to be high and that demand for grassland production insurance is rather low, multi-peril grassland production insurance may struggle to continue unsubsidized.

Originality/value - This paper provides a framework that enables to estimate demand for grassland production insurance factoring in substitution with self-insurance and taking into account successive risks.

Keywords Risk management, Bioeconomic model, Discrete stochastic programming,

Grassland insurance, Index-based insurance, Livestock

Paper type Research paper

\section{Introduction}

Cow-calf operations, also called suckler cow farms, are an important feature of French agriculture: the four million suckler cows supply around 65 percent of the beef production in France and one million weanlings are exported each year. More than

\section{Received 2 February 2015 \\ Revised 23 June 2015 \\ 28 August 2015 \\ 31 August 2015}

Accepted 1 September 2015

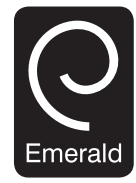

Agricultural Finance Review Vol. 75 No. 4,2015 pp. 533-551 hing Limited

DOI 10.1108/AFR-02-2015-0006 
AFR

75,4

534
80 percent of animal diets come from grasslands. However, grassland production is sensitive to weather conditions, particularly to drought: production loss is above 20 percent of French farm average reference one in seven years for the first cut hay and one in four years for the second cut (Devun et al., 2013). In the event of natural calamities, French farmers can receive indemnities from the national calamity fund. Between 1980 and 2006, forage crops received higher indemnifications from this fund than cash crops, fruits or vegetables (Boyer, 2008). Nowadays, cash crops and vineyard are not anymore eligible to this fund since multi-peril crop insurances are available. So far, grassland production has been considered non-insurable. However, the French government plans to progressively switch from this national calamity fund toward multi-peril grassland insurance. The policy plan includes a subsidy (cofunded by the EU and the French government) of up to 65 percent of the insurance premium and public reinsurance of the insurance companies. However, uncertainties remain regarding the attractiveness and efficiency of such an insurance program[1]. One reason posited by Smith and Glauber (2012) to explain that farmer participation is often well below the levels desired by policymakers (Knight and Coble, 1997), is that farmers may have cheaper ways of managing risk. Self-insurance (on farm risk-reducing activities) and multi-peril grassland insurance can be substitute and complements (Ehrlich and Becker, 1972), consequently, demand for insurance should be assessed taking into account simultaneously self-insurance and multi-peril grassland insurance.

A number of papers have studied the on-farm possibilities for managing grassland production risks in cattle systems (Olson and Mikesell, 1988; Lien and Hardaker, 2001; Mosnier et al., 2011; Briner and Finger, 2013) but few have tackled the grassland production insurance issue while factoring in self-insurance possibilities. Among them, Finger and Calanca (2011) analyzed grassland production risk management strategies for Swiss farmers taking into account grassland production insurance, grass fertilization and decoupled payments. Müller et al. (2011) demonstrated that if a cost-free rangeland production insurance is available, grassland protection (resting part of the pasture area in rainy years) decreases in Namibia. However, these studies underestimate constraints and opportunities tied to livestock production: at best, livestock production is considered proportional to rangeland production at any given time. More recently, Briner et al. (2015) introduced both a gross margin insurance and various on farm risk management possibilities. However, they overlook the possibility for livestock farms to manage grassland production variability thanks to between year adjustments of herd and forage stocks (Kobayashi et al., 2007; Mosnier et al., 2011; Rose et al., 2014).

Different method are used to estimate insurance demand. First econometric methods derive demand from observed crop insurance purchase (Smith and Goodwin, 1996; Coble et al., 1997; Serra et al., 2003; Enjolras et al., 2012) or from survey data on farmers' intent to purchase crop insurance (Shaik et al., 2008). Demand could also be inferred from observed production decisions such as in Sakurai and Reardon (1997). However, these methods used aggregated production functions that don't consider multi-peril grassland insurance decisions together with on-farm risk management strategies. Moreover, econometric models are hardly able to represent the sequential decision-making process (inputs are not all chosen simultaneously) (Antle, 1983). Previous works (Mosnier et al., 2010a, 2014) emphasized that grassland yield shocks involve many ex post production-system adjustments. Pannell et al. (2000) also emphasized the importance of tactical adjustments in risk management. Discrete stochastic programming (DSP) model (Cocks, 1968; Rae, 1971; Apland and Hauer, 1993) 
enables to simulate complex production systems and to consider several decision stages. Following other livestock farm models (Lambert, 1989; Jacquet and Pluvinage, 1997; Lien and Hardaker, 2001; Lien et al., 2007; Briner et al., 2015), we developed a DSP model but between-year dynamics are added.

The purpose of this paper is to investigate demand for multi-peril grassland insurance taking into account substitution possibilities via self-insurance. The paper is organized as follows. Section 2 outlines the operating principles of the national calamity funds and of the future multi-peril grassland insurance. Section 3 describes the bioeconomic model. Section 4 presents the scenarios. Section 5 reports the quantity of multi-peril grassland insurance purchased according to previous years' grassland yields, farm characteristics, risk aversion, insurance loading cost and coverage level. Section 6 discusses results.

\section{The insurance schemes}

\subsection{The national calamity funds}

Under today's legislation in France, farms are eligible to receive indemnities from the national calamity funds when yield falls below 73 percent of regional-average yield (estimation based on an investigation and on a survey of farms) and the value of the damage exceeds 13 percent of theoretical farm sales[2]. A unit of forage is estimated by the administration at $€ 120 / \mathrm{tDM}$ provided farmers can demonstrate this amount of forage is necessary to feed their cattle. Beef cattle farmers received in average $€ 8$ per ha of grassland per year over the period 2000-2009 (Mosnier et al., 2014). Funds are subsidized half by the government and half by taxes (11 percent) on building and machinery insurance premiums (Boyer, 2002). In the studied systems, around $€ 3 /$ ha goes into the fund.

\subsection{The multi-peril grassland insurance}

The French insurer Pacifica launched its new contract for multi-peril grassland insurance in 2015 in partnership with Airbus and Space.

Airbus developed a Forage Production Index (FPI) (Roumiguié et al., 2014) (the Appendix). FPI is the ratio between the cumulated annual grass produced between the 1st of February and the 31st of October, and the Olympic average of annual production of the last five years. Forage production is derived each ten days from the fraction of green vegetation cover. Data are collected by remote sensing measurements with medium spatial resolution time series images calculated at the scale of a $6 \mathrm{~km} \times 6 \mathrm{~km}$ elementary unit that are then disaggregated at municipality level (15 $\mathrm{km}^{2}$ in average).

Variation of forage production is estimated under the assumption that grassland management remains globally constant from year to year at municipality level. If the majority of farmers decide to intensify grazing in response to insurance, economic or political incentives, the green cover fraction would decrease but not real forage production. Nevertheless, it is likely that such changes would be gradually incremented, limiting moral hazard. This index is sold to insurers between $€ 2 /$ ha and $€ 5 /$ ha (the exact value is confidential).

Indemnity payments are made whenever FPI falls below a predetermined level. The levels of coverage proposed range between 50 and 90 percent of average annual grass production. The level of deductible equals the level of coverage. The average capital insured is $€ 800 /$ ha and varies between $€ 600$ and $€ 1000 /$ ha according to the production 
AFR

75,4

536 potential of grasslands. For a loss of 40 percent, with a coverage and deductible of 30 percent, indemnity would reach 10 percent of the capital insured. For an average capital insured of $€ 800 /$ ha and a 25 percent level of coverage, premium before public subsidies is set in average at €30/ha[3]. Yields are expected to fall below 70 percent 1 in 7 or 8 years. Rate of public subsidies on premium allowed by the Common Agricultural Policy (CAP) depends on coverage level, at up to 65, 40 and 20 percent for the 70, 80 and 90 percent coverage levels, respectively.

\section{Description of the stochastic programming model}

\subsection{Model overview}

This model is formulated to represent a French cow-calf enterprise based on grassland production and located in the Massif Central. Cows calve for the first time at three years old and then once a year, in winter. Main products are weanlings between eight and 12-month-old and culled cows.

A DSP framework is used to represent sequential decision making under grassland production risks (Figure 1).

Three states of nature for grassland yield are introduced: catastrophic yield, low yield and normal to very good yield. Emphasize was placed on the left hand tail of the distribution in order to investigate the insurance issue. Stable and hay storage capacities and average grassland use are chosen in stage 0 . Then, each year, the area of grassland insured is fixed ex ante in stage 1 before knowing grassland production. Ex post, in stage 2, production decisions that include animal sales, animal energy intakes, feed composition and feedstuff purchases are defined for each level of

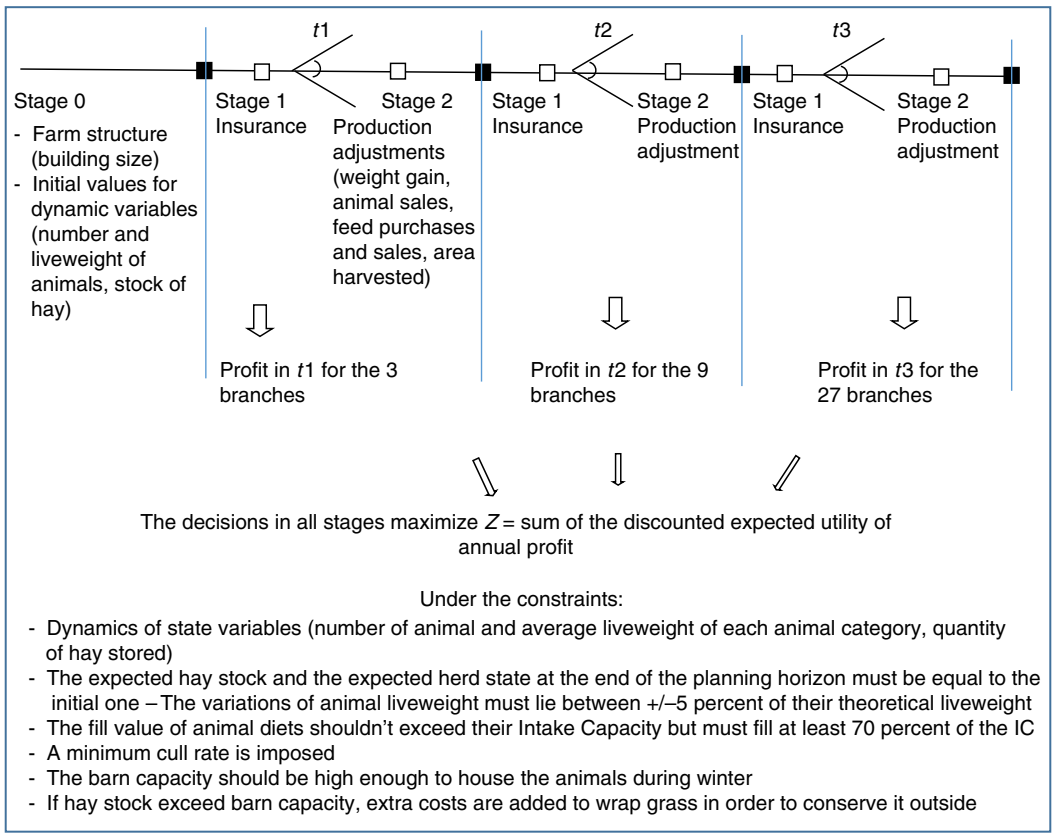

Figure 1.

Outline decision tree under grassland yield risks
Notes: White squares represent decisions and black squares between year evolution of dynamic variables. $<$ Represent states of nature for grassland yields 
grassland yield anticipated. Although a long planning horizon would have been preferable, three years are considered in order to keep the model solvable (33 combinations of production risks are anticipated). However, it provides some flexibility to modify herd size, animal liveweight and forage stock between years and to analyze the effect of successive yield risks. Optimal decisions are those that maximize the sum of discounted expected utility of annual profit. Technically, this model is resolved by the non-linear programming solver CONOPT run in the GAMS software package.

\subsection{The optimization program}

The utility function introduces farmers' preferences toward the distribution of profit (П) for year $t$. A risk-averse farmer would attribute greater utility to a distribution characterized by lower variability and may consequently choose a production plan that does not provide the highest expected profit. Since this application is devoted to insurance, the left-hand tail of the distribution of profit is critical and cornerstone mean-variance model inappropriate (Chavas, 2004). The expected utility model developed by von Neuman and Morgenstern is preferred assuming farmers know the distribution of risks and their impacts. The functional form used here is the power function (Equation (1)) that exhibits decreasing absolute risk aversion and constant relative risk aversion as generally assumed. This means that the lower the level of profit, the higher the penalty applied. The values of relative risk aversion obtained by lottery experiments with French farmers range between 0.1 and 0.75 (Bougherara et al., 2011; Reynaud and Couture, 2012; Roussy et al., 2012). According to (2004)[4] a moderately risk-averse farmer has a relative risk aversion around two and this value is commonly used in empirical works. In order to account for the uncertainty regarding the level of risk aversion, two values are tested: $\gamma=2$ and $\gamma=0.3$. The objective function $Z$ maximizes the discounted expected utility of profit ( $\Pi)$ over a three-year planning horizon (Equation (1)). Each year starts in spring and is divided into six periods $(p)$ of two months:

$$
\operatorname{Max} Z=\sum_{t=1}^{3} \frac{1}{(1-r)^{t-1}} \sum_{\xi 1, \xi 2, \xi 3} \operatorname{prob}(\xi 1, \xi 2, \xi 3) \frac{\prod_{t, \xi 1, \xi 2, \xi 3}{ }^{1-\gamma}}{1-\gamma}
$$

with:

$$
\begin{aligned}
& \Pi_{t, \xi 1, \xi 2, \xi 3}= \\
& \mid \begin{array}{l}
\sum_{p, a}\left(\text { AnimSold }_{\mathrm{t}, p, \xi 1, \xi 2, \xi 3, \mathrm{a}} \times \operatorname{AnimLW}_{\mathrm{t}, p, \xi 1, \xi 2, \xi 3, \mathrm{a}} \times \text { pricea }_{a}\right)+\mathrm{CAPpayment}_{t, \xi 1, \xi 2, \xi 3} \\
+ \text { HaIns }_{t, \xi 1, \xi 2} \times\left(\text { ins_indemn }_{t, \xi 1, \xi 2, \xi 3}-\text { ins_premium }\right)
\end{array} \\
& \mid \begin{array}{l}
\sum_{p, a}\left(\text { AnimSold }_{\mathrm{t}, p, \xi 1, \xi 2, \xi 3, \mathrm{a}} \times \operatorname{AnimLW}_{\mathrm{t}, p, \xi 1, \xi 2, \xi 3, \mathrm{a}} \times \text { pricea }_{a}\right)+\mathrm{CAPpayment}_{t, \xi 1, \xi 2, \xi 3} \\
+ \text { HaIns }_{t, \xi 1, \xi 2} \times\left(\text { ins_indemn }_{t, \xi 1, \xi 2, \xi 3}-\text { ins_premium }\right)
\end{array} \\
& + \text { QSold } \times \text { prices_hay- } \sum_{p, v} \text { QBought }_{t, p, \xi 1, \xi 2, \xi 3, v} \times \text { pricev }_{v}-\sum_{p=1}^{6} \text { ForageProdCost }_{t, p, \xi 1, \xi 2, \xi 3} \\
& -\mathrm{HayStCapac}_{b} \times \text { price_hayst-StableCapac }{ }_{b} \times(\text { price_stable }+ \text { fix_lsu }) \\
& \text {-fix_ha } \times u a a
\end{aligned}
$$

Multi-peril grassland crop insurance 
AFR

75,4

538

where $r$ is the discount rate (0.04), $p\{p 1, p 6\}$ annual sub-periods, and $\xi 1, \xi 2, \xi 3$, $\{C 1, C 2, C 3\}$ the state of nature of grassland production in year $t\{t 1, t 2, t 3\}$. Endogeneous variables $A$ nimL $W$ and AnimSold are, respectively, the number and the average liveweight of animals in class a, CAPpayment is the level of public support reveived, HaIns is the area insured, QBought is the quantity of feed $v$ purchased and QSold the quantity of hay sold. ForageProdCost is linked with forage activity, StableCapac is the size of animal stable, HayStCapac is the hay storage capacity. pricea, privev, prices_hay, price_stable, price_hayst, are, respectively, the price of animals per $\mathrm{kg}$ of liveweight, the purchased price of feed and litter, the hay selling price, the cost of the stable and of the barn. fix_ha and fix_lsu are fixed cost proportional to farm size (respectively, hectare of arable land and herd size).

Decisions made in year $t 1$ differs according to $t 1$ grassland yield but are invariant to yields of years $t 2$ and $t 3$. Consequently, production variables $X$ are constrained as follows:

$$
\mathrm{X}_{\mathrm{t} 1, \xi 1, \xi 2, \xi 3}=X_{\mathrm{t} 1, \xi 1, \mathrm{Cl}, \mathrm{Cl}} \quad \forall(\xi 1, \xi 2, \xi 3)
$$

Since insurance is purchased for the year $t 1$ before knowing grassland production for $t 1$ :

$$
\text { HaIns }_{t 1, \xi 1, \xi 2}=\text { HaIns }_{t 1, C 1, C 1} \quad \forall(\xi 1, \xi 2)
$$

Similar constraints are added for the year $t 2$ :

$$
\mathrm{X}_{\mathrm{t} 2, \xi 1, \xi 2, \xi 3}=X_{\mathrm{t} 2, \xi 1, \xi 2, \mathrm{Cl}} \text { and HaIns } \mathrm{H}_{t, \xi 1, \xi 2}=\text { HaIns }_{t, 2, \xi 1, \mathrm{Cl}}
$$

Other constraints relative to the production system and to the multi-peril grassland insurance are detailed below.

\subsection{Animal production activities and constraints}

To cover the range of animal production, eight annual animal classes characterized by sex (male or female), age (newborn to mature) and production objective (fattening or lean) are introduced in the model. Classes are described by two endogenous dynamic variables: the number of animals and their average liveweight.

The number of animals present (AnimPresent) at the beginning of each period is defined as the difference between the number of animal present at the beginning of the previous period minus the dead and the animals sold (AnimSold) at the end of the previous period (Equation (6)). At the beginning of each year, an animal may change from one class to another due to the natural ageing process (the number of one-year-old heifers at the end of a year becomes the initial number of two-year-old heifers the following year; calf numbers depend on cow numbers) and due to fattening objectives (the share of cows fattened is optimized). Animals could be sold provided that weanlings are older than six months and that there are enough dam to feed them. Cows do not undergo an ageing process. Consequently, a 
minimum cull rate is introduced and set at 0.24 . Animals cannot be purchased, as this rarely happens in the studied systems:

\section{Multi-peril grassland crop insurance}

AnimPresent $_{t, p, \xi, a}=$

$$
\begin{array}{ll}
\text { AnimPresent }_{t, p-1, \xi, a} \times(1-\text { deathrate })-\text { AnimSold }_{t, p-1, \xi, a} & \text { if } p>1 \\
\text { AnimPresent }_{t-1, p-1, \xi, \text { aa }} \times(1-\text { deathrate })-\text { AnimSold }_{t-1, p-1, \xi, \text { aa }} & \text { if } t>1, p=1 \\
\text { InitAnimPresent } & \text { if } t=1, p=1
\end{array}
$$

With "aa", a subscript corresponding to the preceding animal class; $\xi$ shortens grassland yields $\xi 1, \xi 2$ and $\xi 3$

Animal liveweight in a given period depends on liveweight at the previous period and on the balance between energy requirements and energy intake. Feed composition (grazed grass, hay or concentrate feed) and diet energy content are optimized under the constraint that animal liveweights are between \pm 5 percent of their theoretical live weight (+/-35 kg for cows). See Mosnier et al. (2009) for more detailed explanations.

The initial number of animals and their initial liveweight are constrained to be equal to their expected value at the end of the simulation. Herd size could vary between years but because of this constraint, no closing stock value is attributed to animals. The valuation of animal stock is indeed sensitive, above all for female calves that could become reproductive females: under-valuating closing stock caused stock depletion and over-valuating it induces stock accumulation.

\subsection{Grassland production and feed resource constraints}

We consider only grasslands (100 ha). Consequently, concentrate feed and straw are purchased in totality. These grassland areas produce on average 6.9 tons of DM/ha/ year but suffers some losses at grazing ("loss_pat" between 25 and 35 percent depending on season) or haymaking (20 percent during haymaking, harvest and transport). Grassland production varies between years in quantity, quality and their distribution within years. Taking into account all facets of grass production variability would require a very complex model of production forecasting. Here, we choose to focus on variation of total production yields, as do most multi-peril crop insurance programs and to assume that the same deviation to average yield occurs at each different season. Although effects of serious drought, overgrazing or trampling could alter biomass production over several years (Müller et al., 2011), such events are infrequent in the studied system. It is thus assumed that grassland production is independent between years. This assumption could slightly underestimate risk-reducing strategies. Between-year distribution of grassland production is summarized by three states of nature: catastrophic yield (C1: $<70$ percent of average yield), low yield (70 percent $<\mathrm{C} 2:<90$ percent of average yield) and normal to very good yield (C3: > 90 percent of average yield). Average deviations of grassland yield for the three states of nature and probability of occurrence of these states (Table I)

\begin{tabular}{lcccr}
\hline & Catastrophic yield C1 (\%) & Low yield C2 (\%) & Normal to very good yield C3 (\%) & $\begin{array}{r}\text { Table I. } \\
\text { Probability of } \\
\text { average yield } \\
\text { deviation }\end{array}$ \\
$\begin{array}{lcccl}\text { Yield variation } \\
\text { Probability }\end{array}$ & 60 & 81 & 113 & 68 \\
\hline
\end{tabular}


AFR

75,4

540 are parameterized using Isop[5] over the1980-2010 period for the agricultural regions located in the northern part of Massif Central.

The quantity of standing grass available for grazing (QStGrass) corresponds to the balance between previous biomass stock after shedding of dead matter, grass produced and grass exported (grazed or cut). It must be positive or null. Grass production at each period depend on grassland yield ( $y d)$ and on the area not harvested ("uaa-Ha_Harv") which is optimized and fixed for the whole planning horizon. In order to cope with grassland production variation, less (more) grassland area is harvested in the case of low (high) grassland yield. Values are set according to estimations made on real suckler-cow farms (Mosnier et al., 2014) (aj_harv $=-10$ percent of total grassland area for $\mathrm{C} 1 ;-5$ percent for $\mathrm{C} 1$ and +5 percent for $\mathrm{C} 3$ ). When grass use is delayed to the following period, there are losses due to average ageing process and to environmental conditions (abs) (Jouven et al., 2006). At the beginning of the year, the stock of standing grass is assumed to be null:

$$
\begin{aligned}
\operatorname{QStGrass}_{v, t, p, \xi}= & {\left[\begin{array}{l}
\mathrm{QStGrass}_{t, p-1, \xi} \\
-\sum_{a} \text { AnimPresent }_{t}, p-1, \xi, a \times \mathrm{QFeed}_{\text {grass }^{\prime}, t, p-1, \xi, a} \times \text { loss_pat }_{p} \\
+\left(u a a-\mathrm{HA} \_ \text {Harv }\right) \times\left(1-a j \_h a r v_{\xi}\right) \times y d_{p, \xi}
\end{array}\right] } \\
& \times a b s_{p} \text { for } p>1
\end{aligned}
$$

with HA_Harv $\$$ s uaa.

The quantity of hay stored is the next balance from previous stock, hay harvested (which depends on the area harvested and on grassland yield) and hay purchased, and previous hay consumption and hay sold. Hay could be stored over years. Initial stock is constrained to be equal to the expected hay surplus at the end of the planning horizon. This constraint gives incentive to keep hay surplus at the end of the planning horizon and avoids valuing stock variation.

\subsection{Multi-peril grassland insurance}

The characteristics of the multi-peril grassland insurance are inspired by the scheme currently in testing in France. Indemnity payments (Table II) are made whenever annual grass production falls below a predetermined level. This level depends on the coverage option and is specified as percentage $\rho$ of average yield $\bar{Y}$. Each year, the number of hectares insured is optimized. The indemnity payment function is defined as follows, with the value $P$ of damages set at $€ 100$ per ton of dry matter in order to obtain the typical capital insured in this area (personal communication: around $€ 700 / \mathrm{ha}$ ):

$$
\text { Ins_Indem } \xi=\max \left\{0, \rho \bar{Y}-Y_{\xi}\right\} \times P
$$

Table II.

Multi-peril grassland insurance indemnities according to coverage level

\begin{tabular}{lrrc}
\hline & $\mathrm{C} 1$ & $\mathrm{C} 2$ & Expected indemnity \\
\hline Cov. $70 \%$ & 69 & 0 & 8.3 \\
Cov. $80 \%$ & 138 & 0 & 13.8 \\
Cov. $90 \%$ & 207 & 62 & 37.2 \\
\hline
\end{tabular}


The insurance premium is calculated based on the distribution of grassland yield (Table I). It is equal to expected indemnity payment multiplied by a loading factor $\lambda$ that accounts for administration and operations costs:

$$
\text { ins_premium }=\sum_{\xi}\left(\text { prob }(\xi) \times \text { ins_indem }_{\xi}\right) \cdot \lambda
$$

\subsection{Costs and receipts}

Costs are divided into costs that are fixed for the whole planning horizon and costs that could vary with year and grassland production level. They have been estimated according to Réseaux d'Elevage pour le Conseil et la Prospective[6] (2012). Fixed costs encompass amortization and maintenance costs for cattle stable ( $€ 90 /$ unit of livestock capacity) and buildings to store forage (€6/tDM of storage capacity). If herd size or forage stock fall below these capacities, fixed costs do not decrease since farmers still have to finance their investment and the allied maintenance work. Stable capacity is limiting: herd size in winter cannot exceed barn capacity. This is not the case for hay storage capacity: if grass cannot be conserved inside the shed, additional costs are added to wrap grass into bales in plastic film $(+€ 20 / \mathrm{tDM})$ so that they can be stored outside. Other fixed costs are added to account for mechanization costs (€80/100 kg of animal produced), property charges $(€ 30 / \mathrm{kg})$, management costs $(€ 30 / \mathrm{kg})$ and other miscellaneous costs (€20/kg). These fixed costs (around $€ 460 / \mathrm{ha}$ ) have been split into costs proportional to average herd size (€220/LSU) and costs fixed per hectare (€200/ha) during the calibration stage in order that the simulated stocking rate matches to observations (around 1.1 and 1.2 LSU/ha) (Mosnier et al., 2014). Costs per livestock units (LSU) effectively impact optimal herd size.

Variable production costs include fertilizers for grassland (€25/ha) and haymaking (€90/ha), purchased feeds (€150/t of concentrate feed , €140/t of hay in the event of a year with low-grassland production), litter ( $€ 0.42 /$ day/LSU), and miscellaneous extra costs (€90/LU) such as veterinary fees, feed supplements (vitamins, minerals) and rapeseed meal. Hay could be sold at 90€/t. Over the 2008-2012 period, ten-month-old males sold at $€ 2.50 / \mathrm{kg}$, lean cows at $€ 1.69 / \mathrm{kg}$ and fattened cows at $€ 1.80 / \mathrm{kg}$ (all sold live)[7]. The CAP premium specifications encompass suckler cow payments that are proportional to the number of cows ( $€ 188 /$ cow for the first 40 cows and then $€ 169 / \mathrm{cow}$ ), plus other payments from the first and second pillars (€30k). A modulation rate of 10 percent is applied.

\section{Scenarios}

In all, 82 simulations were run in order to analyze the effect of insurance loading cost (14 levels), insurance coverage level (three levels), risk aversion (two levels) and stock levels (stocks vary according to grassland yields in each simulation) on the optimal area insured. A range of loading varying between 0.7 and 2 by 0.1 increments were tested. A loading below one is possible under public subsidies on insurance premium (up to 65 percent); a loading of two is likely based on the French Court of Auditors[8] that pointed out that for the cash crops insurance sector, the premium was twofold higher than the indemnification. The coverage levels proposed by the French insurance company are between 50 and 90 percent of average yield. However, the anticipated grassland yields do not fall below 60 percent. Three levels of insurance coverage are then alternatively proposed: 70,80 or 90 percent. The level of risk aversion is linked to 
AFR

75,4

the amount of money a farmer is ready to forego in order to reduce its exposure to profit loss. Moreover, the level of risk aversion is controversial and is likely to be heterogeneous among farmers. Consequently two contrasted levels of risk aversion are simulated: $r=0.3$ (low) and $r=2$ (moderate) (see also section 3.2).

\section{Results}

The result section is structured as follows. First, focus is on a specific simulation in order to analyze the impacts of year-over-year variation of farm stock levels on the area insured. Second, the optimal area insured is estimated according to loading costs, insurance coverage levels and risk aversion levels. Eventually, we analyze the substitution between the insurance coverage level and farm structure components.

\subsection{Insurance demand according to previous grassland production yields}

This section provides a description of the sequence of decisions, the evolution of dynamic variables and the annual profits in order to better understand the relationships between grassland insurance and other variables over time. Results are given for a 80 percent coverage insurance, a loading cost of 1 (fair premium) and a risk aversion of 0.3 . They are summarized in Table III.

The simulated stable has a capacity of 110 LSU for winter housing. It is always saturated. Decapitalizing cows or future cows is costly for two reasons: cow premiums are proportional to the number of cows and it is not worthwhile to operate below stable capacity because stable place is costly. Adjustments of the number of animals are intra-annual: weanlings are sold at eight-month old in the case of low or catastrophic grassland yields and at ten-month old otherwise; more cows (+0.3) are fattened in C3 (60 percent of culled cows are fattened in average). The number of LSU is consequently higher in $\mathrm{C} 3$ than in $\mathrm{C} 1$, but with variation according to previous years' grassland yields. Liveweight is more variable, especially for multiparous cows and depends on both current and previous years' grassland yields.

The barn enables to store 300 tons of hay, representing 1.6 times the average quantity of hay harvested (191 tons). The quantity harvested each year varies between 98 and 221 tons. 80 tons of hay are available at the beginning of year $t 1$ (14 percent of the average herd consumption). This stock is depleted in the cases of low or catastrophic yields but reaches 105 tons following a good grassland production in $t 1$ (no hay is sold). In the case of catastrophic grassland yield, additional feed is purchased. The closing quantity of hay varies between 0 and 196 tons.

In all, 77 ha of grasslands are insured the first year. It is not optimal to insure the whole grassland area although premium equal expected profit. Net income is lower for $\mathrm{C} 2$ (low yield) than for $\mathrm{C} 1$ (catastrophic yield) since a premium has to be paid in $\mathrm{C} 2 \mathrm{but}$ no indemnity is received. To reduce $\mathrm{C} 2$ loss, less insurance is purchased.

Insurance demand is highly dependent on the previous year's grassland yields. The second year, farmers would insure all their pastures if no hay stock is left from year $t 1$ but would buy insurance only for 46 ha if the initial hay stock reaches 105 tons. The second year the contracted area varies between 11 and 100 ha according to hay stock level and initial herd liveweight.

\subsection{Insurance demand according to their loading cost and to farmers' risk aversion}

Here, is estimated the average area insured over the three year planning horizon according to insurance loading cost and farmers' risk aversion. Insurance is bought at 


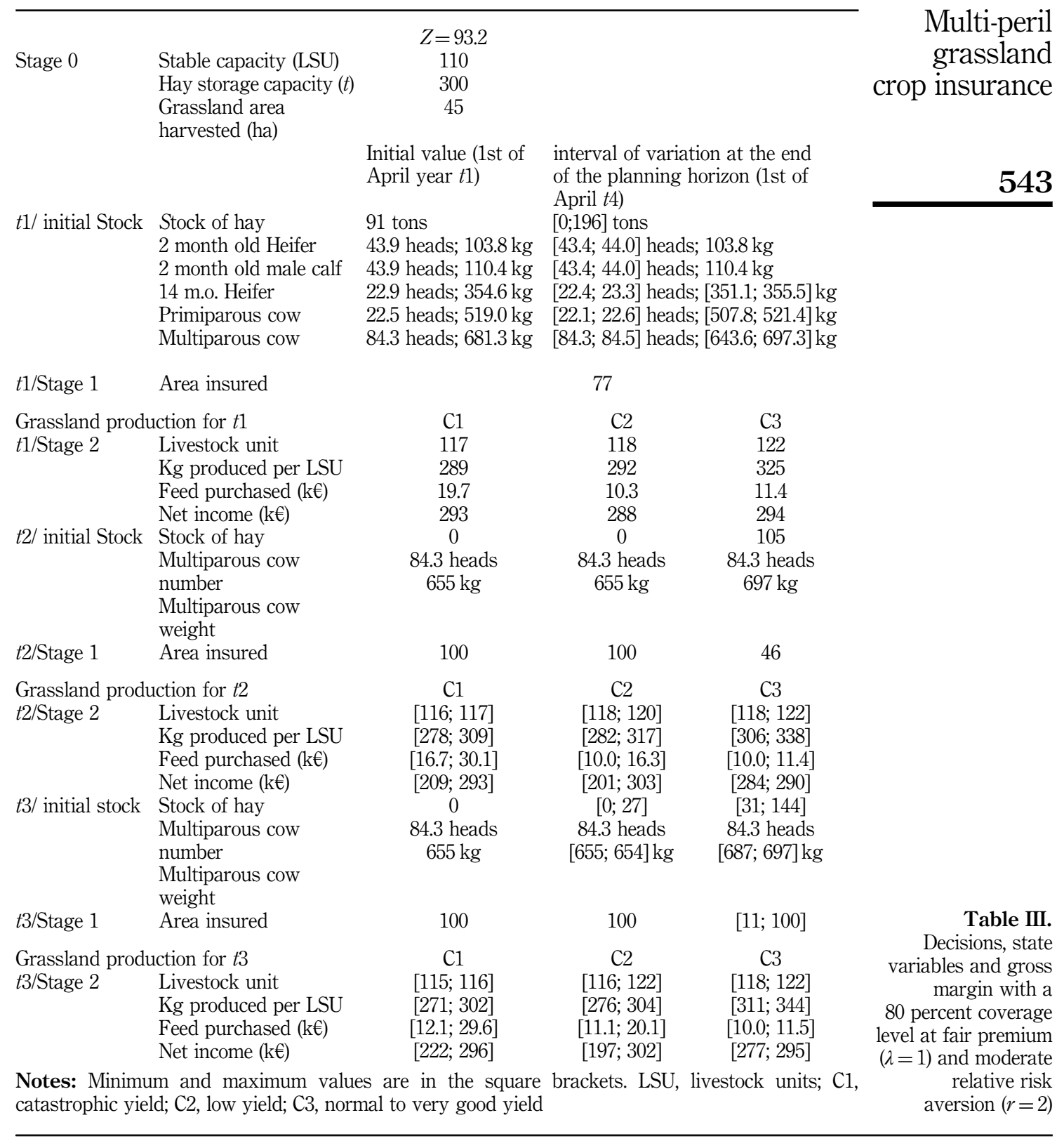

higher prices if risk aversion is moderate rather than low (Figures 2 and 3). A farmer with low-risk aversion would reduce quickly the area insured when insurance premium is above expected profit. Almost no insurance is not purchased if loading exceeds 1.1. A farmer with moderate aversion to risk would be less sensitive to insurance price (elasticity around four). Note that, as explained in the previous section, the whole area is 
AFR

75,4

\section{4}

not always insured when insurance premium is below expected indemnity (insurance premium is reduced in order to increase profit in $\mathrm{C} 2$ which is lower than in $\mathrm{C} 1$ ).

Figures 2 and 3 also show that higher loading costs are paid for lower coverage. The first reason for this is that it gets costlier for farmers to self-insure as loss gets bigger and rare. The second one is that, since the expected indemnity is lower, so is the insurance premium. Therefore, premiums are affordable for states C2 and C3.

\subsection{Relationships between farm structure and insurance demand}

In the stage 0 , farm structure is chosen knowing insurance possibilities for the three next years. The stable capacity increases and the capacity to store hay gets smaller when the insurance coverage level increases (Table IV). The substitutions between

Figure 2.

Average area insured according to insurance loading cost and coverage level for a relative risk aversion of 0.3

Figure 3.

Average area insured according to insurance loading cost and coverage level for a relative risk aversion of 2

\section{Table IV.}

Building capacities according to the levels of insurance coverage and risk aversion
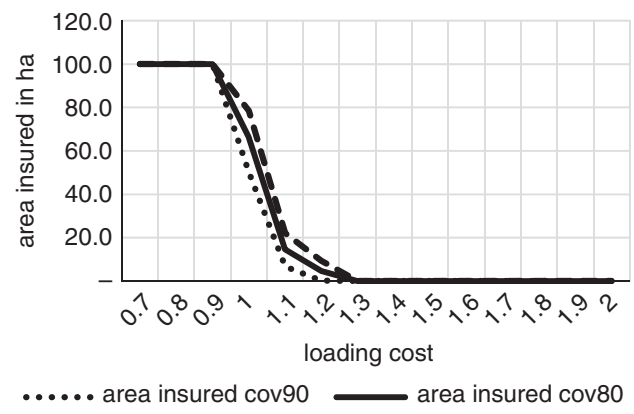

- - area insured cov70

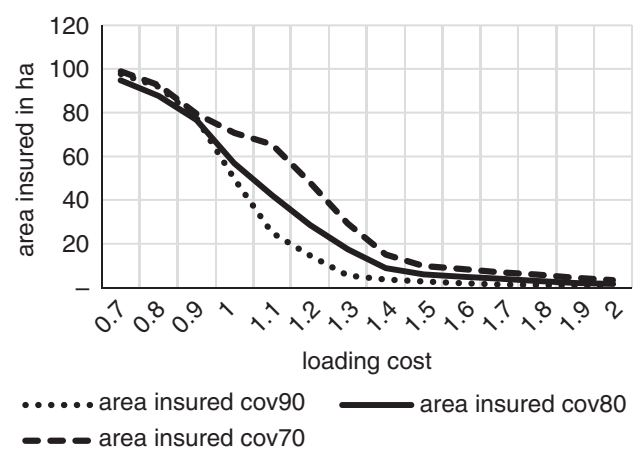

\begin{tabular}{|c|c|c|c|c|c|c|c|c|}
\hline & \multicolumn{4}{|c|}{$R=0.3$} & \multicolumn{4}{|c|}{$R=2$} \\
\hline & $90 \%$ & $80 \%$ & $70 \%$ & 0 & $90 \%$ & $80 \%$ & $70 \%$ & 0 \\
\hline Stable capacity (LSU) & 110.9 & 109.8 & 109.3 & 108.7 & 112.2 & 109.6 & 108.3 & 107. \\
\hline Hay storage capacity (tons) & 276 & 298 & 309 & 320 & 257 & 301 & 312 & 336 \\
\hline Min net income $(€ / \mathrm{ha})$ & 245 & 202 & 150 & 101 & 250 & 230 & 187 & 168 \\
\hline Average net income $(€ / \mathrm{ha})^{\mathrm{a}}$ & 297 & 291 & 288 & 286 & 296 & 290 & 287 & 284 \\
\hline
\end{tabular}

Note: ${ }^{a}$ the average net income is higher when insured because a loading cost of 0.7 is assumed in order to obtain a farm fully insured 
building capacities and grassland insurance are almost double from 80 to 90 percent coverage level than from 0 to 70 percent or 70 to 80 percent: the 70 and 80 percent coverage levels target only the catastrophic grassland yield (C1) and consequently self-insurance is more important for low yields (C2). The 90 percent coverage level also covers $\mathrm{C} 2$. The substitutions are also more important when risk aversion increases because the willingness to reduce profit losses is higher.

Grassland insurance is not only a substitute for self-insurance but also a complement. In spite of substitutions between grassland insurance and self-insurance, a higher coverage level still raises the minimum net income obtained over the planning horizon.

\section{Multi-peril grassland crop insurance}

\section{Discussion}

Our results show clear interactions between self-insurance and grassland insurance. The simulated on-farm risk management strategy consists ex ante in reducing stable capacity (and consequently average herd size) and to increase the hay storage capacity. This is consistent with previous empirical (Mosnier et al.,2010b) and simulation studies (Mosnier et al., 2011; Briner et al., 2015) that found that lower stocking rate reduces risks of shortfalls in fodder. We assumed that farm structure and grassland insurance are chosen simultaneously, which is not true at short or mid-term. Nonetheless, it may be inferred that farmers who have higher storage possibilities and relatively low-stocking rate would have less interest in buying grassland insurance.

Main ex post adjustments targets hay stock and feed purchase. This is consistent with the literature that finds supplementary feeding is a key element of grassland risk management (Diaz-Solis et al., 2006; Kobayashi et al., 2007; Veysset et al., 2007; Mosnier et al., 2009, 2014; Briner et al., 2015). The more expensive and scarce are feed substitutes on the market, the more incentives farmers would have to reduce their stocking rate and to purchase grassland insurance.

The inter-annual analysis shows that the quantity of feed stock available and animal liveweight before purchasing insurance are decisive drivers of demand for grassland insurance. Grassland insurance is here a flexible risk management tool, used when the farm becomes vulnerable to fodder shortfall. Nonetheless, although this flexibility appears as an interesting advantage of grassland insurance, farmers and insurers may not be keen on making different contracts each year.

According to our simulations, farmers would be ready to pay higher than 110 percent of expected indemnity (loading cost $>1.1$ ) only in the case of moderate risk aversion (not with low-risk aversion); the expected area insured falls below 50 percent of the total grassland area when loading cost is above 1.2 and are almost null above 1.3. These values are in line with other studies. A survey of 141 French beef cattle and sheep-for-meat producers (Mosnier et al., 2014) found that the average willingness to pay corresponds to a loading cost of 1.2 and the median value around 0.9 (the estimated value of capital was nonetheless 50 percent higher than in our study); only 35 percent of the farmers were willing to consider insurance. An econometric analysis by Patrick (1988) found that only a minority of farmers were interested by an insurance on wheat and they were not willing to pay more than 110 percent of the actuarially fair premium rate. Briner et al. (2015), using a DSP model, find that gross margin insurance with a fair premium was not purchased by Swiss cow-calf farmers.

This willingness to pay could have been overestimated. First, some broader insurance substitutes have not been included: farmers could choose to carry lower dept or to maintain savings, contingent credit could be available for emergency; other on farm (diversifying forage production or agricultural activities) and off farm risk 
AFR

75,4 management strategies exist; various government programs could also interact with the forage production insurance scheme.

Second, subjective probabilities may also distort reality. The likeliness of catastrophic events is often underestimated (Kahneman and Tversky, 1979; Kunreuther, 1996) and consequently insurance could appear too expensive to farmers.

Eventually, basis risks, which correspond to the discrepancy between index and real production, have not been considered. If an index fails to provide indemnities when the farm experiences losses, farmers would pay less for this insurance (Smith and Glauber, 2012). Satellite-based information is still a recent development that has not yet proved itself (McLaurin and Turvey, 2011; Leblois and Quirion, 2013). The FPI performs quite well but correlations between this index and real grassland production are imperfect. The method to derive forage production from satellite images explains between 0.71 and 0.90 of observed variability $\left(R^{2}\right)$ (Roumiguie et al., 2015b). Errors relative to the spatial resolution must be added: $R^{2}$ between high-resolution estimates $(10 \mathrm{mx} 10 \mathrm{~m})$ and moderate resolution $(6 \mathrm{~km} \times 6$ $\mathrm{km}$ ) range between 0.78 and 0.93 (Roumiguié et al., 2015a). The obligation for farmers to insure their whole grassland area partially offset spatial basis risk. Nevertheless, basis risks are high enough to trigger inappropriate indemnifications in some cases. The consequences of these risks should be estimated in further research.

With 65 percent of subsidies it would be optimal for farmers to insure the totality of their grasslands with the 70 percent coverage level, up to very high-loading costs. However, some farmers may be reluctant to advance the full cost of insurance premium - particularly in times of economic downturn (Binswanger-Mkhize, 2012) - and to spend time to complete administrative formality for refunding. Ideally, subsidies on insurance should be removed after a transitional period (Tangermann, 2011). This transitional period corresponds to the time necessary to reduce uncertainties regarding the distribution of risks and to recruit farmers. Nonetheless, if insurers take advantage of public subsidies to increase premium rates more than necessary, the rate of penetration of insurance could remain low. Load for yield insurance in France (around two according to French Court of Auditors) appears quite high compared to other European countries (between 1.3 and 1.6, Bielza Diaz-Caneja et al., 2009). In order to encourage insurers to decrease their price, loads should be transparent for the government to guarantee that subsidies really decrease insurance premium and do not only increase insurers' profit. Competitiveness in the agricultural sector insurance should be promoted too (Bielza Diaz-Caneja et al., 2009).

\section{Conclusions}

From the perspectives of the probable replacement of the national calamity funds by multi-peril grassland insurance, the objective of this study was to estimate demand for grassland production insurance factoring in substitution with self-insurance. We used a DSP model with three year planning horizon to run a series of simulations. Our results show that grassland insurance could be used as a flexible risk management tool, when farm becomes vulnerable to fodder shortfall. According to previous years' grassland yields and to the subsequent states of hay stock and animal liveweight, the area insured could vary between nearly the none and full. Farmers with low-average stocking rates and important hay storage capacity have less incentive to buy grassland insurance. We also demonstrate that for a given loading cost, more insurance is purchased at a coverage level of 70 percent of average yield than at higher coverage levels. The cost of self-insurance increases for important and rare losses while multi-peril grassland insurance premium decreases. Higher levels of risk aversion also 
raise the quantity of insurance subscribed. Eventually, insurance price is a key factor. Almost no insurance is bought for loading costs greater than 1.1 under low-risk aversion and for loading costs greater than 1.3 under moderate risk aversion.

Considering that the loading cost is likely to be high and that demand for grassland production insurance is low, multi-peril grassland production insurance may struggle to continue unsubsidized. Nevertheless, reducing herd size alone would not prevent farmers from important profit losses in the case of catastrophic grassland yield, advocating for maintaining safety net programs. Other self-insurance options and public emergency measures such as subsidized loan or reduction in social security contributions should also be considered to assess and reduce farmers vulnerability to risks.

\section{Acknowledgments}

The author would like to thank C.G. Turvey, the anonymous reviewers, A. Gohin, A. Reynaud and L. Piet for their valuable comments and suggestions to improve this paper, G. Sigel (Airbus Defence and Space) and C. Fongarnand (Crédit Agricole) for their insider information on grassland insurance, the collaborators, from previous research who contributed to the model development or the empirical analysis cited, Inosys-Réseaux d'Elevage and the Inra beef cattle farm databases used here for model calibration and validation.

\section{Notes}

1. French Ministry of Agriculture: N/Réf: cn 0708784 V/Réf: Référé no. 65,742.

2. www.legifrance.gouv.fr/jopdf/common/jo_pdf.jsp?numJO $=0 \&$ dateJO $=20120118 \&$ numTexte $=31$ \&pageDebut $=00997 \&$ pageFin $=01001$

3. www.lafranceagricole.fr/actualite-agricole/assurance-prairie-pacifica-lance-son-nouveaucontrat-104305.html\#YiiwWdOCIBYTR0LR.99

4. Note that this value is set in Hardaker et al. (2004) in reference to total wealth which is equal to certain wealth plus variable income. Certain wealth is assumed to correspond to decoupled CAP premium minus fixed costs, and variable income corresponds to gross margin.

5. The Isop device is implemented by the Inra, Meteo France and the SSP French Ministry for Agriculture Office of Statistics and Trend Studies (SSP). Grassland yields are estimated using a version of the STICS model for grasslands. www.agreste.agriculture.gouv.fr/IMG/ pdf/syntheseprairie0904.pdf

6. Résultats 2010 des exploitations bovin viande, estimations des revenus pour 2011, collection Résultats Annuels, 56p. www.sl.chambagri.fr/uploads/media/2010-synthese_nationale_ suivis_02.pdf

7. Réseaux d'élevage and IPPAP index: www.insee.fr/fr/themes/info-rapide.asp?id $=80$

8. Ministry of Agriculture: ref. No. cn 0708784 V/Ref : summary procedure No. 65,742, March 25, 2013.

\section{References}

Antle, J.M. (1983), "Sequential decision-making in production models", Am I Agr Econ, Vol. 65 No. 2, pp. 282-290.

Apland, J. and Hauer, G. (1993), "Discrete stochastic programming: Concepts, examples and a review of empirical applications", No 13793, Staff Papers from University of Minnesota, Department of Applied Economics. 
AFR

75,4

548

Bielza Diaz-Caneja, M., Conte, C.G. and Gallego Pinilla, F.J. (2009), "Risk management and agricultural insurance schemes in Europe", JRC Reference Reports, JRC51982, available at: http://publications.jrc.ec.europa.eu/repository/bitstream/JRC51982/lr_ipsc_reference_report_ agriculture_insurance.pdf (accessed October 2015).

Binswanger-Mkhize, H.P. (2012), "Is there too much hype about index-based agricultural insurance?”, LDev Stud, Vol. 48 No. 2, pp. 187-200.

Bougherara, D., Gassmann, X. and Piet, L. (2011), "A structural estimation of French farmers' risk preferences: an artefactual field experiment”, Working Paper SMART - LERECO, No 11-06, Inra, 21p.

Boyer, P. (2002), "Le système français de protection contre les risques de la production agricole et ses évolutions récentes", International Conference on Agricultural Insurance, May 12 and 13, Madrid.

Boyer, P. (2008), “Assurer les calamités agricoles?”, Notes et études économiques, Vol. 30, pp. 7-32.

Briner, S. and Finger, R. (2013), "The effect of price and production risks on optimal farm plans in Swiss dairy production considering 2 different milk quota systems", LDairy Sci, Vol. 96 No. 4, pp. 2234-2246.

Briner, S., Lehmann, N. and Finger, R. (2015), "Bio-economic modelling of decisions under yield and price risk for suckler cow farms”, Animal Production Science, Vol. 55 No. 1, pp. 64-73.

Chavas, J.-P. (2004), Risk Analysis in Theory and Practice, Academic Press.

Coble, K.H., Knight, T.O., Pope, R.D. and Williams, J.R. (1997), “An expected-indemnity approach to the measurement of moral hazard in crop insurance", Am I Agr Econ, Vol. 79 No. 1, pp. 216-226.

Cocks, K. (1968), "Discrete stochastic programming”, Management Science, Vol. 15 No. 1, pp. 72-79.

Devun, J., Moreau, J.C., Lherm, M. and Mosnier, C. (2013), "Interannual variability of forage production between 2000 and 2011. Analysis per region based on farm surveys", Fourrages, Vol. 215, pp. 221-230.

Diaz-Solis, H., Kothmann, M.M., Grant, W.E. and De Luna-Villarreal, R. (2006), “Application of a simple ecological sustainability simulator (SESS) as a management tool in the semi-arid rangelands of northeastern Mexico", Agricultural Systems, Vol. 88 Nos 2-3, pp. 514-527.

Ehrlich, I. and Becker, G.S. (1972), "Market insurance, self-insurance, and self-protection”, The Journal of Political Economv, Vol. 80 No. 4, pp. 623-648.

Enjolras, G., Capitanio, F. and Adinolfi, F. (2012), "The demand for crop insurance. Combined approaches for France and Italy”, Agricultural Economics Review, Vol. 13 No. 1, pp. 5-15.

Finger, R. and Calanca, P. (2011), "Risk management strategies to cope with climate change in grassland production: an illustrative case study for the Swiss plateau", Reg Environ Change, Vol. 11 No. 4, pp. 935-949.

Hardaker, J.B., Huirne, R.B., Anderson, J.R. and Lien, G. (2004), Coping with Risk in Agriculture, 2nd ed., CABI publishing.

Jacquet, F. and Pluvinage, J. (1997), "Climatic uncertainty and farm policy: a discrete stochastic programming model for cereal-livestock farms in Glgeria”, Agricultural Svstems, Vol. 53 No. 4, pp. 387-407.

Jouven, M., Carrere, P. and Baumont, R. (2006), "Model predicting dynamics of biomass, structure and digestibility of herbage in managed permanent pastures. 1. Model description”, Grass and Forage Science, Vol. 61 No. 2, pp. 112-124. 
Kahneman, D. and Tversky, A. (1979), "Prospect theory: an analysis of decision under risk", Econometrica: Iournal of the Econometric Society, Vol. 47 No. 2, pp. 263-291.

Knight, T.O. and Coble, K.H. (1997), "Survey of US multiple peril crop insurance literature since 1980", Rev Agr Econ, Vol. 19 No. 1, pp. 128-156.

Kobayashi, M., Howitt, R.E., Jarvis, L.S. and Laca, E.A. (2007), "Stochastic rangeland use under capital constraints", Am I Agr Econ, Vol. 89 No. 3, pp. 805-817.

Kunreuther, H. (1996), "Mitigating disaster losses through insurance", Lournal of Risk and Uncertainty, Vol. 12 Nos 2-3, pp. 171-187.

Lambert, D.K. (1989), "Calf retention and production decisions over time", Western Journal of Agricultural Economics, Vol. 14 No. 1, pp. 9-19.

Leblois, A. and Quirion, P. (2013), "Agricultural insurances based on meteorological indices: realizations, methods and research challenges", Meteorological Applications, Vol. 20 No. 1, pp. 1-9.

Lien, G. and Hardaker, J.B. (2001), "Whole-farm planning under uncertainty: impacts of subsidy scheme and utility function on portfolio choice in Norwegian agriculture", European Review of Agricultural Economics, Vol. 28 No. 1, pp. 17-36.

Lien, G., Hardaker, J.B. and Flaten, O. (2007), "Risk and economic sustainability of crop farming systems”, Agricultural Svstems, Vol. 94 No. 2, pp. 541-552.

McLaurin, M.K. and Turvey, C.G. (2011), "Applicability of the normalized difference vegetation index in index-based crop insurance design", available at: SSRN: http://ssrn.com/ abstract=1776467 or http://dx.doi.org/10.2139/ssrn.1776467

Mosnier, C., Agabriel, J., Lherm, M. and Reynaud, A. (2009), “A dynamic bio-economic model to simulate optimal adjustments of suckler cow farm management to production and market shocks in France", Agricultural Sustems, Vol. 102 Nos 1-3, pp. 77-88.

Mosnier, C., Agabriel, J., Lherm, M. and Reynaud, A. (2011), "On-farm weather risk management in suckler cow farms: a recursive discrete stochastic programming approach", in Flichman, G. (Ed.), Bio-Economic Models applied to Agricultural Svstems, Springer, pp. 137-154.

Mosnier, C., Agabriel, J., Veysset, P., Bebin, D. and Lherm, M. (2010a), "Evolution and sensitivity to hazards of technical and economic indicators of suckler cow farms according to different production systems: a panel data analysis of 55 French Charolais farms from 1987 to 2007", Prod Anim, Vol. 23 No. 1, pp. 91-101.

Mosnier, C., Agabriel, J., Veysset, P., Bebin, D. and Lherm, M. (2010b), "Évolution et sensibilité aux aléas des résultats technico-économiques des exploitations de bovins allaitants selon les profils de production. Analyse d'un panel de 55 exploitations du bassin Charolais de 1987 à 2007", Inra Prod. Anim, Vol. 23 No. 1, pp. 91-102.

Mosnier, C., Fourdin, S., Moreau, J.C., Boutry, A., Le Floch, E., Lherm, M. and Devun, J. (2014), "Sensitivity of sheep and beef farms to climate risk and attractiveness of grassland insurance", (published in French), Notes et études socio-économiques, Vol. 38, pp. 73-94.

Müller, B., Quaas, M.F., Frank, K. and Baumgärtner, S. (2011), "Pitfalls and potential of institutional change: rain-index insurance and the sustainability of rangeland management”, Ecological Economics, Vol. 70 No. 11, pp. 2137-2144.

Olson, K.D. and Mikesell, C.L. (1988), "The range stocking decision and stochastic forage production”, Staff Paper P88-16, Department of Applied Economics, University of Minnesota, available at: http://purl.umn.edu/13502 (accessed October 2015).

Pannell, D.J., Malcolm, B. and Kingwell, R.S. (2000), "Are we risking too much? Perspectives on risk in farm modeling", Agr Econ, Vol. 23 No. 1, pp. 69-78. 
AFR

75,4
Patrick, G.F. (1988), "Mallee wheat farmers' demand for crop and rainfall insurance”, Australian Journal of Agricultural and Resource Economics, Vol. 32 No. 1, pp. 37-49.

Rae, A.N. (1971), "Stochastic programming, utility, and sequential decision problems in farm management”, Am I Agr Econ, Vol. 53 No. 3, pp. 448-460.

Reynaud, A. and Couture, S. (2012), "Stability of risk preference measures: results from a field experiment on French farmers", Theor Decis, Vol. 73 No. 2, pp. 203-221.

Rose, G., Mulder, H., Thompson, A., van der Werf, J. and van Arendonk, J. (2014), "Varying pasture growth and commodity prices change the value of traits in sheep breeding objectives", Agricultural Svstems, Vol. 131, pp. 94-104.

Roumiguié, A., Jacquin, A., Sigel, G., Poilvé, H. and Lepoivre, B. (2014), “A risk management solution for forage production monitoring in France. Development of an index-based insurance using fCover time series from satellite images", GV2M conference, Avignon, February 7.

Roumiguié, A., Jacquin, A., Sigel, G., Poilvé, H., Hagolle, O. and Daydé, J. (2015a), "Validation of a forage production index (FPI) derived from MODIS fCover time-series using high-resolution satellite imagery: methodology, results and opportunities", Remote Sensing, Vol. 7 No. 9, pp. 11525-11550.

Roumiguié, A., Jacquin, A., Sigel, G., Poilvé, H., Lepoivre, B. and Hagolle, O. (2015b), "Development of an index-based insurance product: validation of a forage production index derived from medium spatial resolution fCover time series", GIScience \& Remote Sensing, Vol. 52 No. 1, pp. 94-113.

Roussy, C., Ridier, A., Chaib, K., Reynaud, A. and Couture, S. (2012), "A methodological way of evaluating innovative cropping systems integrating risk beliefs and risk preferences", Proc. 6. Journées de recherches en sciences sociales (JRSS), Toulouse, December 13-14,, p. 29.

Sakurai, T. and Reardon, T. (1997), "Potential demand for drought insurance in Burkina Faso and its determinants”, Am I Agr Econ, Vol. 79 No. 4, pp. 1193-1207.

Serra, T., Goodwin, B.K. and Featherstone, A.M. (2003), "Modeling changes in the US demand for crop insurance during the 1990s", Agricultural Finance Review, Vol. 63 No. 2, pp. 109-125.

Shaik, S., Coble, K.H., Knight, T.O., Baquet, A.E. and Patrick, G.F. (2008), "Crop revenue and yield insurance demand: a subjective probability approach", Journal of Agricultural and Applied Economics, Vol. 40 No. 3, pp. 757-766.

Smith, V.H. and Glauber, J.W. (2012), "Agricultural insurance in developed countries: where have we been and where are we going?", Applied Economic Perspectives and Policy, pp. 1-28.

Smith, V.H. and Goodwin, B.K. (1996), "Crop insurance, moral hazard, and agricultural chemical use”, Am I Agr Econ, Vol. 78 No. 2, pp. 428-438.

Tangermann, S. (2011), "Risk management in agriculture and the future of the EU's common agricultural policy", ICTSD, Issue Paper (34).

Veysset, P., Bebin, D. and Lherm, M. (2007), "Impacts de la sècheresse 2003 sur les résultats technico-économiques en élevage bovin allaitant charolais”, Fourrages, Vol. 191, pp. 311-322.

\section{About the author}

Claire Mosnier is a Researcher at INRA working on microeconomics of livestock production systems. Claire Mosnier can be contacted at: cmosnier@clermont.inra.fr 


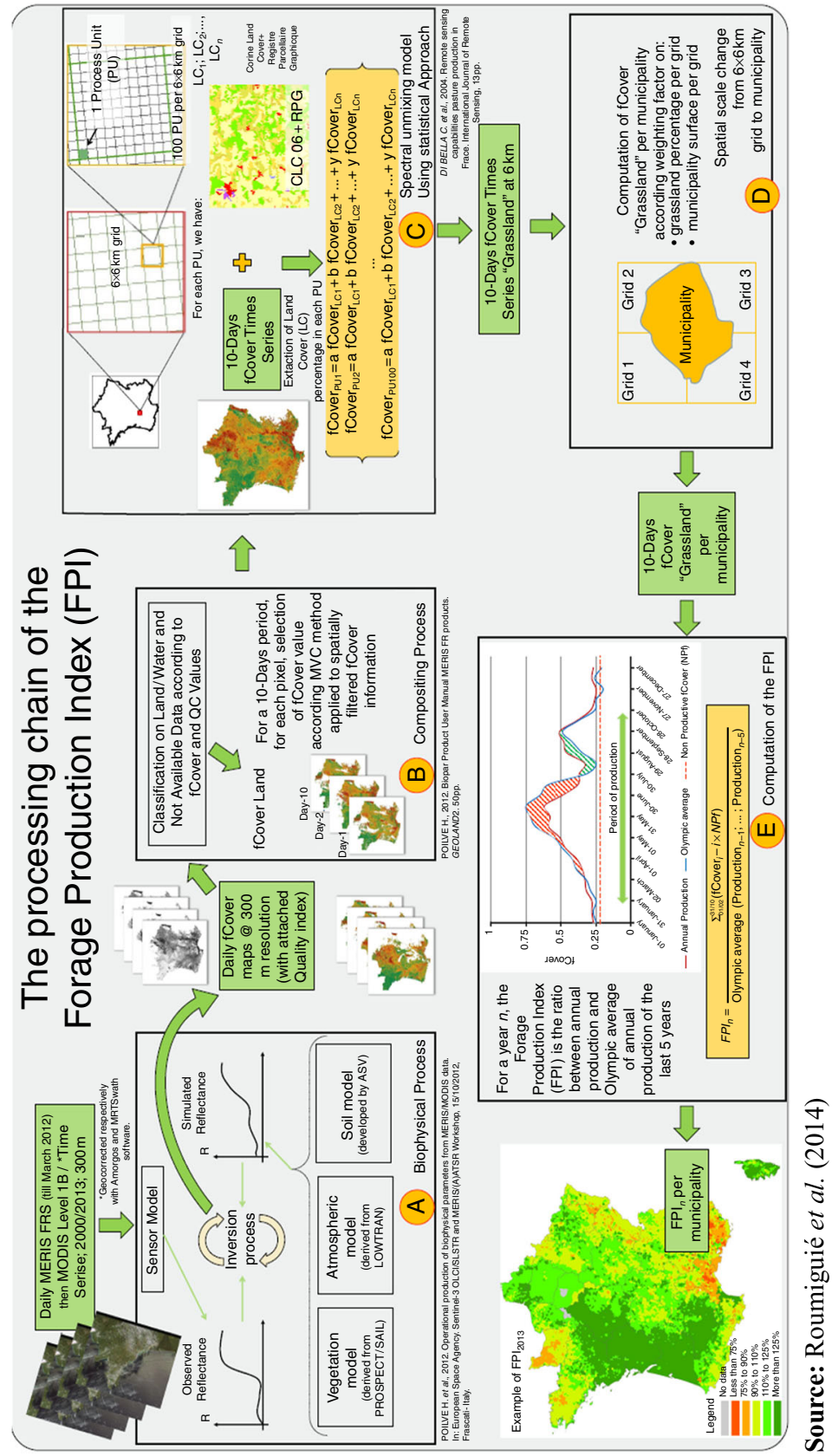

551

Figure A1.

The processing chain of the Forage Production Index 